\title{
DETERMINAN DIABETES MELITUS TIPE 2 DI KELURAHAN TALANG BAKUNG KOTA JAMBI
}

\section{Determinants Of Type 2 Diabetes Mellitus in Talang Bakung Village Jambi City}

\author{
Desi $^{1}$, Willia Novita Eka Rini ${ }^{2}$, dan Rd. Halim ${ }^{2}$ \\ ${ }^{1}$ Program Studi Kesehatan Masyarakat, FKM Universitas Jambi \\ ${ }^{2}$ Dosen Ilmu Kesehatan Masyarakat FKM Universitas Jambi
}

\begin{abstract}
Abstrak
Prevalensi diabetes melitus meningkat secara global, nasional, maupun regional, dan sebagian besar merupakan diabetes melitus tipe 2, dapat menyebabkan komplikasi, kerugian ekonomi, serta kematian. Tujuan penelitian ini untuk mengetahui determinan diabetes melitus tipe 2. Desain studi case-control pada 60 responden yang diambil secara random sampling. Analisis bivariat menggunakan chi square test $(95 \% \mathrm{CI}, \alpha=0,05)$, untuk melihat hubungan usia, jenis kelamin, riwayat keluarga, aktivitas fisik, dan kebiasaa makan dengan kejadian diabetes melitus tipe 2 di Kelurahan Talang Bakung Kota Jambi. Penelitian dilakukan selama September 2017-Juli 2018. Mayoritas responden $(71,67 \%)$ berusia $\geq 45$ tahun, $(66,67 \%)$ perempuan, $(61,67 \%)$ ibu rumah tangga, $(38,33 \%)$ tamat SLTA/sederajat, (65,00\%) tidak ada riwayat keluarga diabetes, (48,33\%) melakukan aktivitas fisik sedang, dan $(91,67 \%)$ memiliki kebiasaan makan tidak baik. Faktor risiko yang berhubungan dengan kejadian diabetes melitus tipe 2 adalah usia $(\mathrm{OR}=4,97 ; 95 \% \mathrm{CI} 1,39-17,82)$ dan riwayat keluarga $(\mathrm{OR}=4,00 ; 95 \% \mathrm{CI} 1,27$ 12,58). Faktor risiko yang tidak berhubungan dengan kejadian diabetes melitus tipe 2 adalah jenis kelamin $(\mathrm{OR}=1,00 ; 95 \% \mathrm{CI} 0,34-2,93)$, aktivitas fisik sedang $(\mathrm{OR}=0,93 ; 95 \% \mathrm{CI} 0,16-5,42)$, aktivitas ringan $(\mathrm{OR}=1,08$; 95\% CI0,18-6,44), dan kebiasaan makan $(\mathrm{OR}=1,56$; 95\% CI 0,24-10,05). Usia dan riwayat keluarga merupakan faktor risiko yang berhubungan dengan kejadian diabetes melitus tipe 2. Oleh karena itu perlu dilakukan deteksi dini, monitoring, peningkatan promosi kesehatan terkait faktor risiko, gejala, dan komplikasi diabetes melitus tipe 2 .
\end{abstract}

Kata Kunci: Determinan, diabetes melitus tipe 2.

\begin{abstract}
The prevalence of diabetes mellitus is increasing globally, nationally and regionally, and most of them are type 2 diabetes mellitus, causes complications, economic loss, and death. The aim of this study was to knowed the determinants of type 2 diabetes mellitus. Case-control study design on 60 respondents taken by random sampling. Bivariate analysis used chi square test ( $95 \% \mathrm{CI}, \alpha=0,05)$, to see the relationship of age, gender, family history, physical activity, and dietary habit with the incidence of type 2 diabetes mellitus. The study was conducted in Talang Bakung Village, Jambi City, during September 2017-July 2018. The majority of respondents $(71,67 \%)$ were $\geq 45$ years old, $(66,67 \%)$ female, $(61,67 \%)$ housewive, $(38,33 \%)$ graduated from high school/equivalent, $(65,00 \%)$ no family history of diabetes, $(48,33 \%)$ doing moderate physical activity, and $(91,67 \%)$ having poor dietary habit. Risk factors associated with type 2 diabetes mellitus are age $(\mathrm{OR}=4,97$; 95\%CI1,39-17,82) and family history $(\mathrm{OR}=4,00 ; 95 \% \mathrm{CI} 1,27-12,58)$. Risk factors that are not related to type 2 diabetes mellitus are gender $(\mathrm{OR}=1,00 ; 95 \% \mathrm{CI} 0,34-2,93)$, moderate physical activity $(\mathrm{OR}=0,93,95 \% \mathrm{CI} 0,16$ $5,42)$, light activity $(\mathrm{OR}=1,08 ; 95 \% \mathrm{CI} 0,18-6,44)$, and dietary habit $(\mathrm{OR}=1,56 ; 95 \% \mathrm{CI} 0,24-10,05)$. Age and family history are risk factors that relate to type 2 diabetes mellitus. Therefore, early detection, monitoring, improvement of health promotion related to risk factors, symptoms, and complications of type 2 diabetes mellitus are necessary.
\end{abstract}

Keywords: Determinants, type 2 diabetes mellitus.

Korespondensi: Desi

Email: apriantidesi75@yahoo.com 


\section{PENDAHULUAN}

Diabetes adalah penyakit kronis serius yang terjadi baik saat pankreas tidak cukup menghasilkan insulin (hormon yang mengatur gula darah atau glukosa), atau bila tubuh tidak dapat secara efektif menggunakan insulin yang dihasilkannya ${ }^{1}$. Jenis diabetes yang umum terjadi dan banyak diderita orang yaitu diabetes melitus tipe 1 dan diabetes melitus tipe $2^{2}$. Namun $90 \%$ penderita diabetes di seluruh dunia merupakan diabetes melitus tipe $2^{3}$.

Pada tahun 2012, terdapat 1,5 juta kematian di seluruh dunia secara langsung disebabkan oleh diabetes $^{1}$. Pada tahun 2015 prevalensi diabetes secara global mencapai $8,8 \%$ dan diperkirakan akan meningkat menjadi $10,4 \%$ di tahun 2040. Jumlah penderita diabetes sebanyak 415 juta jiwa di tahun 2015 yaitu pada usia (20-79 tahun) dan diperkirakan akan meningkat menjadi 642 juta jiwa di tahun 2040. Jumlah kematian yang disebabkan oleh diabetes sebanyak 5,0 juta jiwa di tahun 2015 . Di tahun 2017 jumlah penderita diabetes melitus pada usia (20-79 tahun) di seluruh dunia sebanyak 425 juta jiwa dan diperkirakan akan meningkat menjadi 629 juta jiwa di tahun 2045. Indonesia menempati peringkat kedua kasus diabetes melitus terbanyak di wilayah barat Pasifik setelah China yang berada di peringkat pertama ${ }^{4}$.

Di Indonesia, dari hasil Riskesdas Indonesia prevalensi diabetes melitus sebesar $1,5 \%$ pada tahun 2007 dan meningkat menjadi $2,1 \%$ pada tahun 2013. Di Provinsi Jambi, dari hasil Riskesdas provinsi Jambi prevalensi diabetes melitus sebesar 0,5\% pada tahun 2007 meningkat menjadi 1,1\% pada tahun 2013. Dari jumlah Kabupaten Kota di Provinsi Jambi pada tahun 2007 prevalensi diabetes melitus tertinggi berada di Kabupaten Merangin dan Sarolangun yaitu sebesar 2,7\%, tetapi mengalami penurunan di tahun 2013, sedangkan di Kota Jambi prevalensinya justru meningkat yaitu sebesar 1,2\% pada tahun 2007 menjadi 2,0\% pada tahun 2013,5,7,8. Prevalensi diabetes melitus di Puskesmas Talang Bakung mengalami peningkatan yaitu $1,8 \%$ pada tahun 2015 dan $87,8 \%$ merupakan diabetes tipe 2 dan pada tahun 2016 prevalensinya menjadi $2,0 \%$ dan $88,8 \%$ merupakan diabetes melitus tipe $2^{9}$.

Semua jenis diabetes dapat menyebabkan banyak komplikasi di bagian tubuh serta dapat meningkatkan risiko kematian secara dini.
Kemungkinan komplikasi yang terjadi diantaranya adalah serangan jantung, gagal ginjal, stroke, amputasi kaki, kehilangan penglihatan dan kerusakan saraf. Komplikasi diabetes melitus membawa kerugian ekonomi yang besar baik pada penderita, keluarga, sistem kesehatan, maupun ekonomi nasional melalui biaya medis, serta hilangnya upah karena kehilangan pekerjaan. Sementara itu, pemakaian biaya utama adalah perawatan di rumah sakit dan rawat jalan, dan kenaikan biaya untuk insulin yang semakin diresepkan ${ }^{1}$.

Secara umum kelompok masyarakat yang mempunyai risiko tinggi (high risk) diabetes melitus antara lain usia lebih dari 45 tahun, berat badan lebih atau IMT $>23 \mathrm{~kg} / \mathrm{m}$, hipertensi, ibu dengan riwayat melahirkan bayi $>4000$ gram, pernah diabetes sewaktu hamil, riwayat keturunan diabetes melitus, kolesterol HDL $<35 \mathrm{mg} / \mathrm{dl}$ atau trigliserida $>250 \mathrm{mg} / \mathrm{dl}$, kurang aktivitas fisik, autoimunitas, virus atau zat kimia, pola makan yang tidak seimbang, gangguan toleransi glukosa, lemak dalam darah, riwayat abortus berulang, eklamsi, dan bayi lahir mati ${ }^{10,2,11}$. Dari beberapa banyak faktor penyebab diabetes melitus, faktor usia, jenis kelamin, riwayat keluarga, aktivitas fisik, dan kebiasaan makan adalah faktor risiko yang paling besar hubungannya dengan kejadian diabetes melitus tipe 2 .

\section{METODE}

Penelitian ini menggunakan desain kuantitatif yang bersifat analitik dengan metode case control, dimana observasi atau pengukuran variabel bebas dan variabel terikat tidak dilakukan pada saat yang bersamaan. Penelitian dilakukan di Kelurahan Talang Bakung Kecamatan Paal Merah Kota Jambi dimulai dari September 2017 sampai dengan Juli 2018. Sampel dalam penelitian ini sebanyak 60 orang yang terdiri dari 30 kasus (orang yang didiagnosis diabetes melitus tipe 2 oleh dokter di puskesmas Talang Bakung uisa $\geq 15$ tahun) dan 30 kontrol (orang yang tidak diabetes melitus tipe 2 usia $\geq 15$ tahun). Teknik sampling yang digunakan yaitu probability samples dengan menggunakan simple random sampling. Analisis data dilakukan dengan dua tahapan yaitu analisis univariat dan analisis bivariat dengan uji chi square. Tingkat signifikan $\mathrm{p}=0,05$ dan tingkat kepercayaan sebesar $95 \%$. 


\section{HASIL DAN PEMBAHASAN}

Tabel 4.5 Distribusi Frekuensi Responden berdasarkan Karakteristik Responden di Kelurahan Talang Bakung Tahun 2017

\begin{tabular}{|c|c|c|}
\hline Variabel & Jumlah (n) & Persentase (\%) \\
\hline \multicolumn{3}{|l|}{ Usia } \\
\hline$\geq 45$ tahun & 43 & 71,67 \\
\hline$<45$ tahun & 17 & 28,33 \\
\hline \multicolumn{3}{|l|}{ Jenis kelamin } \\
\hline Perempuan & 40 & 66,67 \\
\hline Laki-laki & 20 & 33,33 \\
\hline \multicolumn{3}{|l|}{ Pekerjaan } \\
\hline PNS/TNI/POLRI/BUMN/BUMD & 11 & 18,33 \\
\hline Pegawai swasta & 3 & 5,00 \\
\hline Wiraswasta & 5 & 8,33 \\
\hline Buruh & 4 & 6,67 \\
\hline Ibu rumah tangga & 37 & 61,67 \\
\hline \multicolumn{3}{|l|}{ Pendidikan } \\
\hline Tidak/belum pernah sekolah & 3 & 5,00 \\
\hline Tidak tamat SD/MI & 5 & 8,33 \\
\hline Tamat SD/MI & 11 & 18,33 \\
\hline Tamat SLTP/MTS & 10 & 16,67 \\
\hline Tamat SLTA/MA & 23 & 38,33 \\
\hline Tamat D1/D2/D3 & 1 & 1,67 \\
\hline Tamat PT & 7 & 11,67 \\
\hline \multicolumn{3}{|l|}{ Riwayat keluarga DM } \\
\hline $\mathrm{Ya}$ & 21 & 35,00 \\
\hline Tidak & 39 & 65,00 \\
\hline \multicolumn{3}{|l|}{ Anggota Keluarga DM } \\
\hline Ibu kandung & 8 & 30,76 \\
\hline Saudara kandung & 8 & 30,76 \\
\hline Anak kandung & 3 & 11,54 \\
\hline Om/paman kandung & 3 & 11,54 \\
\hline Tante/bibi & 2 & 7,69 \\
\hline Nenek kandung & 1 & 3,85 \\
\hline Ayah & 1 & 3,85 \\
\hline \multicolumn{3}{|l|}{ Aktivitas fisik } \\
\hline Ringan & 25 & 41,67 \\
\hline Sedang & 29 & 48,33 \\
\hline Berat & 6 & 10 \\
\hline \multicolumn{3}{|l|}{ Kebiasaan makan } \\
\hline Tidak baik & 55 & 91,67 \\
\hline Baik & 5 & 8,33 \\
\hline
\end{tabular}

Tabel 4.5 menunjukan bahwa mayoritas responden 43 orang $(71,67 \%)$ berusia $\geq 45$ tahun berjenis kelamin perempuan 40 orang $(66,67 \%)$, bekerja sebagai ibu rumah tangga 37 orang $(61,67 \%)$, menamatkan pendidikan pada tingkat SLTA/sederajat 23 orang $(38,88 \%)$, tidak memiliki anggota keluarga dengan diabetes melitus 39 orang (65\%), melakukan aktivitas fisik sedang 29 orang $(48,33 \%)$, dan hampir seluruhnya 55 orang $(91,67 \%)$ memiliki kebiasaan makan tidak baik yaitu mengkonsumsi makanan/minuman manis $\geq 3$ kali perminggu.

\section{Hubungan Faktor Risiko dengan Diabetes Melitus Tipe 2}

Berdasarkan hasil analisis bivariat faktor risiko dengan kejadian diabetes melitus tipe 2 diperoleh hasil sebagai berikut. 
Tabel 4.6 Hubungan Faktor Risiko dengan Kejadian Diabetes Melitus Tipe 2

\begin{tabular}{|c|c|c|c|c|c|c|}
\hline \multirow[t]{2}{*}{ Variabel } & \multicolumn{2}{|c|}{ Diabetes melitus tipe 2} & \multirow[t]{2}{*}{ Jumlah (\%) } & \multirow[t]{2}{*}{ OR } & \multirow[t]{2}{*}{$95 \% \mathrm{CI}$} & \multirow{2}{*}{$\begin{array}{c}P \\
\text { Value }\end{array}$} \\
\hline & Kasus (\%) & Kontrol (\%) & & & & \\
\hline \multicolumn{7}{|l|}{$\overline{\text { Usia }}$} \\
\hline$\geq 45$ & $26(86,67)$ & $17(56,67)$ & $43(71,67)$ & 4,97 & $1,39-17,82$ & 0,022 \\
\hline$<45$ & $4(13,33)$ & $13(40,00)$ & $17(28,33)$ & & & \\
\hline \multicolumn{7}{|l|}{ Jenis Kelamin } \\
\hline Perempuan & $20(66,67)$ & $20(66,67)$ & $40(66,67)$ & 1,00 & $0,34-2,93$ & 1,000 \\
\hline Laki-laki & $10(33,33)$ & $10(33,33)$ & $20(33,33)$ & & & \\
\hline \multicolumn{7}{|c|}{ Riwayat Keluarga } \\
\hline $\mathrm{Ya}$ & $15(50,00)$ & $6(20,00)$ & $21(35,00)$ & 4,00 & $1,27-12,58$ & 0,030 \\
\hline Tidak & $15(50,00)$ & $24(80,00)$ & $39(65,00)$ & & & \\
\hline \multicolumn{7}{|l|}{ Aktivitas fisik } \\
\hline Ringan & $12(40,00)$ & $13(43,33)$ & $25(41,67)$ & 1,08 & $0,18-6,44$ & 0,963 \\
\hline Sedang & $15(50,00)$ & $14(46,67)$ & $29(48,33)$ & 0,93 & $0,16-5,42$ & \\
\hline Berat & $3(10,00)$ & $3(10,00)$ & $6(10,00)$ & & & \\
\hline \multicolumn{7}{|c|}{ Kebiasaan makan } \\
\hline Tidak baik & $28(93,33)$ & $27(90,00)$ & $55(91,67)$ & 1,56 & $0,24-10,05$ & 1,000 \\
\hline Baik & $2(6,67)$ & $3(10,00)$ & $5(8,33)$ & & & \\
\hline
\end{tabular}

Tabel 4.6 menunjukkan bahwa proporsi responden yang berusia $\geq 45$ tahun lebih banyak 26 (86,67\%) pada kelompok kasus dibandingkan dengan kelompok kontrol 17 (56,67\%), baik kelompok kasus maupun kontrol lebih

banyak $20(66,67 \%)$ responden perempuan, adanya riwayat keluarga dengan diabetes melitus lebih banyak $15(50,00 \%)$ pada kelompok kasus daripada kelompok kotrol 6 (20,00\%), responden yang melakukan aktivitas fisik sedang lebih banyak 15 $(50,00 \%)$ pada kelompok kasus dibandingkan dengan kelpmpok kontrol 14 (46,67\%), dan responden yang pola makannya tidak baik lebih banyak $28(93,33 \%)$ pada kelompok kasus dibandingkan dengan kelompok kontrol 27 (90,00\%).

Hasil analisis diketahui bahwa faktor risiko yang berhubungan dengan kejadian diabetes melitus tipe 2 di Kelurahan Talang Bakung Kota Jambi adalah usia $(\mathrm{OR}=4,97$; 95\%CI 1,39-17,82) dan riwayat keluarga ( $\mathrm{OR}=4,000 ; 95 \% \mathrm{CI} 1,27-12,58)$. Faktor risiko yang tidak berhubungan dengan kejadian diabetes melitus tipe 2 di Kelurahan Talang Bakung Kota Jambi adalah jenis kelamin $(\mathrm{OR}=1,000 ; 95 \% \mathrm{CI} 0,34-2,93)$, aktivitas fisik ringan (OR=1,08; 95\%CI0,18-6,44), aktivitas fisik sedang ( $\mathrm{OR}=0,93$; 95\% CI0,16-5,42), dan kebiasaan makan $(\mathrm{OR}=1,56$; 95\%CI 0,24-10,05). Dari hasil uji regresi logistik diketahui bahwa aktivitas fisik ringan diperoleh nilai $\mathrm{OR}=1,08$ dan aktivitas fisik sedang diperoleh nilai $\mathrm{OR}=0,9$ dengan aktivitas fisik berat sebagai pembanding.

\section{PEMBAHASAN}

Hasil penelitian ini diketahui bahwa terdapat 2 dari 5 variabel yang diteliti memiliki hubungan yang signifikan dengan kejadian diabetes melitus tipe 2 di Kelurahan Talang Bakung Kota Jambi, yaitu variabel usia dan riwayat keluarga, sedangkan faktor risiko jenis kelamin, aktivitas fisik, dan kebiasaan makan tidak berhubungan dengan kejadian diabetes melitus tipe 2 di Kelurahan Talang Bakung Kota Jambi.

\section{Usia}

Berdasarkan hasil analisis antara usia dengan kejadian diabetes melitus tipe 2, responden yang pertama kali didiagnosis diabetes melitus tipe 2 pada usia $\geq 45$ tahun lebih tinggi dibandingkan dengan responden yang pertama kali didiagnosis diabetes melitus tipe 2 pada usia $<45$ tahun. Pada penelitian ini orang yang berusia $\geq 45$ tahun berisiko lima kali untuk terkena diabetes melitus tipe 2 dibandingkan dengan orang yang berusia $<45$ tahun. Sesuai dengan faktor risiko diabetes melitus tipe 2, bahwa diantara kelompok usia diabetes melitus yang lebih besar yaitu usia $>45$ tahun.

Hasil penelitian ini didukung oleh penelitian Sharma, R \& Prajapati, P.K subjek terbesar mengalami diabetes melitus pada kelompok usia 5160 tahun ( $\geq 45$ tahun). Kekuatan fisik dan mekanisme pertahanan tubuh cenderung menurun dengan bertambahnya usia dan tubuh tidak lagi mampu menghadapi pilihan gaya hidup yang tidak sehat, yang pada akhirnya menghasilkan manifestasi penyakit seperti diabetes. Diperkirakan bahwa pada 
tahun 2030 di seluruh dunia, jumlah terbesar individu dengan diabetes adalah usia 45-64 tahun ${ }^{12}$. Pelitian ini juga sejalan dengan penelitian Rahajeng, Ekowati (2010) bahwa orang yang berusia antara 41-64 tahun berisiko enam kali lebih untuk terkena diabetes melitus tipe 2 dibandingkan dengan orang yang berusia antara 25-40 tahun $^{13}$.

Menurut Smeltzer dan Bare (2008), mayoritas penderita diabetes melitus tipe 2 paling banyak dialami oleh orang-orang berada di usia 40 tahun ke atas. Hal ini disebabkan karena pada umur 40 tahun ke atas retensi insulin pada diabetes melitus tipe 2 akan semakin meningkat di samping terdapat riwayat keturunan dan obesitas. WHO mengasumsikan bahwa setelah umur 30 tahun, maka kadar glukosa darah akan naik 1-2 mg/dL/tahun sedangkan pada saat puasa akan naik 5,6-13 mg/dL pada saat 2 jam setelah makan ${ }^{14}$. Meskipun pada umumnya diabetes melitus terjadi pada usia pertengahan atau pada orang yang lanjut usia. Namun, seiring dengan epidemik global, terdapat tren diabetes melitus tipe 2 muncul pada usia yang lebih awal ${ }^{15}$. Usia merupakan faktor risiko yang tidak dapat diubah dan tidak dapat dihindari, sementara itu semakin bertambahnya usia fungsi tubuh semakin menurun dan berisiko untuk terkena diabetes melitus tipe 2. Meskipun pada penelitian ini yang berisiko adalah usia $\geq 45$ tahun namun tidak menutup kemungkinan bahwa masyarakat dapat terkenan diabetes melitus pada usia $<45$ tahun.

\section{Jenis Kelamin}

Hasil penelitian ini menunjukkan bahwa mayoritas responden berjenis kelamin perempuan, dan tidak terdapat hubungan yang signifikan antara jenis kelamin dengan kejadian diabetes melitus tipe 2 di Kelurahan Talang Bakung Kota Jambi. Sesuai dengan hasil penelitian yang dilakukan oleh Rahmanian et al (2013) dalam penelitiannya, prevalensi diabetes melitus lebih banyak pada perempuan dibandingkan dengan laki-laki. Meskipun demikian, tidak ada perbedaan yang signifikan antara jenis kelamin dengan kejadian diabetes melitus tipe 2. Ini mungkin karena aktivitas fisik yang kurang pada perempuan dibandingkan dengan laki-laki ${ }^{16}$. Didukung oleh hasil penelitian yang dilakukan Silva, Ferreira, \& Pinho, yang mana hasil penelitiannya menunjukkan tidak ada hubungan yang signifikan antara jenis kelamin dengan kejadian diabetes melitus tipe $2^{17}$

Namun berbeda dengan penelitian yang dilakukan oleh Prasetyani \& Sodikin (2017), hasil penelitiannya menunjukkan bahwa mayoritas responden adalah perempuan dan terdapat hubungan yang signifikan antara jenis kelamin dengan kejadian diabetes melitus tipe 2 . Tingginya kejadian diabetes melitus pada perempuan dapat disebabkan oleh adanya perbedaan komposisi tubuh dan perbedaan kadar hormon seksual antara perempuan dan laki-laki dewasa. Perempuan memiliki jaringan adiposa lebih banyak dibandingkan laki-laki. Hal ini dapat diketahui dari perbedaan kadar lemak normal antara laki-laki dan perempuan dewasa, dimana pada lakilaki berkisar antara 15-20\% sedangkan pada perempuan berkisar antara 20-25\% dari berat badan Penurunan konsentrasi hormon estrogen pada perempuan menopause menyebabkan peningkatan cadangan lemak tubuh terutama di daerah abdomen yang akan meningkatkan pengeluaran asam lemak bebas Kedua kondisi ini menyebabkan resistensi insulin $^{18}$

Penelitian Meidikayanti \& Wahyuni mayoritas responden penelitiannya sebesar $90 \%$ berjenis kelamin perempuan. Hal ini sesuai dengan pernyataan Taylor (2010), yang menyatakan bahwa penyebab utama banyaknya perempuan terkena diabetes tipe 2 karena terjadinya penurunan hormon estrogen terutama saat masa menopause. Hormon estrogen dan progesteron memiliki kemampuan untuk meningkatkan respons insulin di dalam darah. Pada saat masa menopause terjadi, maka respons akan insulin menurun akibat hormon estrogen dan progesteron yang rendah. Faktorfaktor lain yang berpengaruh adalah body massa index perempuan yang sering tidak ideal sehingga hal ini dapat menurunkan sensitivitas respons insulin. Hal inilah yang membuat wanita sering terkena diabetes daripada laki-laki ${ }^{14}$.

Tidak ada hubungan antara jenis kelamin dengan kejadian diabetes melitus tipe 2 pada penelitian ini kemungkinan karena responden yang tidak diabetes juga lebih banyak pada perempuan dibandingkan dengan laki-laki. Namun baik perempuan maupun laki-laki hendaknya lebih berhati-hati terhadap penyakit diabetes melitus dan berupaya untuk menjaga kadar gula darah dengan mengubah kebiasaan makan dan aktivitas fisik, serta menghindari hal-hal yang dapat menimbulkan peningkatan indek masa tubuh dan meningkatkan kadar gula darah.

\section{Riwayat Keluarga}

Hasil analisis antara riwayat keluarga diabetes melitus dengan kejadian diabetes melitus tipe 2 
bahwa sebagian besar responden yang tidak memiliki riwayat keluarga diabetes melitus tidak terkena diabetes melitus tipe 2 , dan responden yang memiliki riwayat keluarga diabetes melitus berisiko empat kali untuk terkena diabetes melitus tipe 2. Pada penelitian ini, anggota keluarga yang paling banyak menderita diabetes melitus adalah ibu kandung dan saudara kandung.

Sesuai dengan hasil penelitian yang dilakukan oleh Sakurai, M., dkk terdapat hubungan yang signifikan antara riwayat keluarga diabetes dengan kejadian diabetes melitus tipe 2 . Responden dengan keluarga diabetes melitus memiliki risiko yang lebih tinggi untuk terjadi diabetes melitus tipe 2 dibandingkan dengan orang yang tidak ada riwayat keluarga diabetes ${ }^{19}$. Penelitian lain terkait faktor risiko diabetes melitus tipe 2 , terdapat hubungan antara riwayat keluarga dengan kejadian diabetes melitus tipe 2 dan orang yang memiliki riwayat keluarga diabetes melitus berisiko 6 kali lebih untuk terkena diabetes melitus tipe 2 dibandingkan dengan orang yang tidak memiliki riwayat keluarga diabetes melitus ${ }^{20}$

Ada interaksi yang kompleks dari faktor genetik dan lingkungan pada diabetes Tipe 2. Pada kelompok yang memiliki keluarga dengan diabetes melitus cenderung mengalami diabetes dua hingga enam kali lipat dibandingkan dengan yang tidak memiliki keluarga dengan diabetes melitus. Jika seorang ibu memiliki diabetes melitus, risiko mengembangkannya sekitar 2-4 persen, jika seorang ayah memiliki diabetes melitus, risiko mengembangkannya sekitar 6-9 persen, jika kedua orang tua memiliki diabetes melitus, risiko pengembangannya hingga 30 persen, jika saudara laki-laki atau perempua risiko pengembangannya adalah 10 persen, dan meningkat menjadi 10-19 persen untuk kembar non-identik dan 30-70 persen untuk kembar identik ${ }^{21}$.

\section{Aktivitas Fisik}

Hasil analisis antara variabel aktivitas fisik dengan kejadian diabetes melitus tipe 2 bahwa tidak terdapat hubungan yang signifikan, akan tetapi semakin ringan aktivitas fisik yang dilakukan lebih cenderung berisiko sampai enam kali untuk terkena diabetes melitus tipe 2, sedangkan responden yang melakukan aktivitas fisik sedang justru dapat mengurangi risiko terkena diabetes melitus tipe 2 . Responden baik kasus maupun kontrol, sebagian besar bekerja sebagai ibu rumah tangga, dan mayoritas responden melakukan aktivitas fisik sedang. Pekerjaan sehari-hari yang mereka kerjakan yaitu seperti menyapu halaman, mengepel rumah, mencuci baju dan bercocok tanam. Hasil uji tidak signifikan kemungkinan adanya bias. Adapun salah satu bias yang mungkin terjadi adalah bias informasi, dimana responden lupa mengingat aktivitas fisik yang rutin dilakukan serta lamanya mengerjakan aktivitas tersebut. Kemungkinan orang yang melakukan aktivitas fisik ringan waktu istirahatnya atau waktu tidurnya cukup sedangkan orang yang aktivitas fisiknya berat atau sedang kurang waktu istirahatnya atau waktu tidurnya. Penelitian yang dilakukan oleh Tentero dkk (2016) terdapat hubungan diabetes melitus dengan kualitas tidur. Salah satu kebutuhan dasar setiap individu terutama paseien diabetes melitus yang harus dipenuhi yaitu tidur yang cukup. Tidur yang kurang/ oarang yang memiliki gangguan tidur secara fisiologis dapat mempengaruhi peningkatan kadar gula darah ${ }^{22}$

Ketidak signifikanan ini juga kemungkinan karena orang yang tidak melakukan aktivitas fisik dengan cukup tidak mengalami obesitas. Obesitas merupakan faktor risiko diabetes melitus tipe 2 . Seperti hasil penelitian Noermalawati \& Wirjatmadi (2014) terdapat hubungan yang signifikan antara obesitas dengan kadar gula darah puasa pasien diabetes melitus tipe 2. Menurut Tandra, individu dengan obesitas sentral memiliki tekanan darah tinggi, disertai kadar glukosa darah dan lemak melebihi batas normal. Seseorang dengan Indeks Massa Tubuh (IMT) diatas 25 berisiko $25 \%$ untuk mengalami diabetes dan peningkatan ukuran lingkar perut dan panggul terutama pada obesitas tipe sentral, dapat mengakibatkan resistensi insulin sehingga terjadi diabetes ${ }^{23}$.

Hasil penelitian ini didukung oleh penelitian yang dilakukan oleh Nur dkk bahwa korelasi antara aktivitas fisik dengan kajadian diabetes melitus tipe 2 , tidak ada hubungan antara ativitas fisik dengan kejadian diabetes melitus tipe 2 . Hasil penelitiannya menunjukkan bahwa pasien diabetes melitus yang melakukan aktivitas sedang dan tidak pernah olahraga sebagian besar kadar gula darahnya tidak terkontrol. Sedangkan pasien diabetes melitus yang melakukan aktivitas ringan dan melakukan olahraga kurang dari tiga kali dalam seminggu, hanya satu pasien yang kadar gula darahnya terkontrol ${ }^{24}$.

Berbeda dengan hasil penelitian yang dilakukan oleh Paramitha bahwa hasil analisis antara aktivitas fisik dengan peningkatan kadar gula darah pasien diabetes melitus tipe 2, terdapat hubungan yang 
bermakna antara aktivitas fisik dengan peningkatan kadar gula darah pasien diabetes melitus tipe 2 . Penyerapan glukosa oleh jaringan tubuh pada saat istirahat membutuhkan insulin, sedangkan pada otot yang aktif tidak disertai kenaikan kadar insulin walaupun kebutuan glukosa meningkat. Hal ini dikarenakan pada waktu seseorang beraktivitas fisik, terjadi peningkatan kepekaan reseptor insulin di otot yang aktif. Masalah utama yang terjadi pada diabetes melitus tipe 2 adalah terjadinya resistensi insulin yang menyebabkan glukosa tidak dapat masuk ke dalam sel. Saat seseorang melakukan aktivitas fisik, akan terjadi kontraksi otot yang pada akhirnya akan mempermudah glukosa masuk ke dalam sel. Hal tersebut berarti saat seseorang beraktivitas fisik, akan menurunkan resistensi insulin dan pada akhirnya akan menurunkan kadar gula darah ${ }^{25}$.

Aktifitas fisik dapat mengontrol gula darah. Glukosa akan diubah menjadi energi pada saat beraktivitas fisik. Aktivitas fisik mengakibatkan insulin semakin meningkat sehingga kadar gula dalam darah akan berkurang. Pada orang yang jarang melakukan aktivitas fisik, zat makanan yang masuk kedalam tubuh tidak dibakar tetapi ditimbun dalam tubuh sebagai lemak dan gula. Jika insulin tidak mencukupi untuk mengubah glukosa menjadi energi maka akan timbul diabetes melitus ${ }^{26}$.

\section{Kebiasaan Makan}

Kebiasaan makan dalam penelitian ini yaitu kebiasan mengkonsumsi makanan berisiko yaitu makanan/minuman manis dan makanan olahan dari tepung terigu (mie instan, mie basah, roti, dan biskuit). Responden dikatakan pola makannya tidak baik jika sering mengkonsumsi makanan/minuman manis dan makanan olahan dari tepung terigu. Dikatakan sering jika mengkonsumsi $\geq 3$ kali per minggu. Responden dikatakan kebiasaan makannya baik jika jarang mengkonsumsi makanan/minuman manis dan makanan olahan dari tepung terigu. Dikatakan jarang jika mengkonsumsi $<3$ kali per minggu.

Hasil analisis antara kebiasaan makan dengan kejadian diabetes melitus tipe 2 diperoleh tidak terdapat hubungan yang signifikan. Akan tetapi orang yang kebiasaan makannya tidak baik lebih berisiko untuk terkena diabetes melitus tipe 2 dibandingkan dengan orang yang kebiasaan makannya baik. Hasil penelitian yang dilakukan oleh Abidah, Nur., dkk bahwa pola makan makanan manis, berlemak dan asin berhubungan signifikan dengan kejadian diabetes melitus tipe 2. Konsumsi makanan asin berisiko diabetes melitus sebesar 2,62 kali. Sedangkan konsumsi makanan manis dan berlemak berisiko lebih rendah terkena diabetes melitus tipe $2^{24}$.

Penelitian lain yang dilakukan oleh Iroth, dkk, hasil penelitiannya menunjukkan pola makan mengkonsumsi karbohidrat dan protein berisiko hampir tiga kali untuk terkena diabetes melitus tipe $2^{27}$. Sejalan dengan penelitian yang dilakukan oleh Dolongseda, dkk juga menyatakan bahwa seseorang dengan pola makan tidak baik dapat meningkatkan kadar gula darah dalam tubuh dikarenakan frekuensi makan yang tidak teratur pada penderita diabetes melitus tipe $2^{28}$.

Suatu penelitian yang dilakukan terhadap pasien diabetes dengan tingkat kontrol glikemik yang berbeda. Tidak ada perbedaan rata-rata kadar glukosa plasma harian atau profil glukosa dengan asupan karbohidrat, dan tidak ada hubungan antara lemak makanan dengan diabetes melitus tipe 2. Banyak studi prospektif menemukan hubungan antara asupan lemak dan risiko berikutnya mengembangkan diabetes melitus tipe 2. Dalam studi diabetes, yang dilakukan di San Louis Valley, lebih dari seribu subjek tanpa diagnosis diabetes sebelumnya, dan diselidiki secara prospektif selama 4 tahun, dalam penelitian itu, para peneliti menemukan hubungan antara asupan lemak terhadap diabetes melitus tipe 2 dan gangguan toleransi glukosa. Studi lain mengamati hubungan berbagai komponen diet di antara dua kelompok wanita, termasuk lemak, serat ditambah sukrosa, dan risiko diabetes melitus tipe 2 . Setelah penyesuaian, tidak ada hubungan yang ditemukan antara asupan lemak, sukrosa, karbohidrat atau serat dan risiko diabetes pada kedua kelompok tersebut $^{29}$.

Hasil penelitian antara kebiasaan makan dengan kejadian diabetes melitus tipe 2 pada penelitian ini tidak signifikan kemungkinan karena responden yang tidak diabetes sebagian besar juga memiliki kebiasaan mengkonsumsi makanan/minuman manis dan makanan olahan dari tepung terigu. Selain itu, ada kemungkinan bahwa responden selain mengkonsumsi makanan/minuman manis dan olahan dari tepung terigu juga mengkonsumsi makanan yang mengandung serat seperti sayur dan buah, sehingga kadar gula darahnya tetap terjaga. Peneliti juga tidak melakukan penelitian berapa banyak jumlah makanan berisiko yang dikonsumsi tetapi hanya meneliti seberapa sering responden mengkonsumsi makanan berisiko tersebut. 
Serat merupakan elemen penting dalam persediaan makanan kita yang hilang ketika makanan diproses Serat merupakan komponen penting untuk diet sehat karena berbagai alasan, tetapi tugas yang paling penting adalah membantu menjaga keseimbangan kadar gula darah dan insulin di dalam tubuh. Diet makanan olahan, ketika makanan diproses, itu dapat mempengaruhi indeks glikemik makanan. Semakin banyak makanan diproses, semakin tinggi respon glikemik yang akan dihasilkan ${ }^{30}$.

\section{KESIMPULAN DAN SARAN}

Hasil penelitian determinan kejadian diabetes melitus tipe 2 di Kelurahan Talang Bakung Kota Jambi, maka dapat disimpulkan bahwa dari 60 responden yang diteliti $43(71,67 \%)$ berusia $\geq 45$ tahun, $40(66,67 \%)$ berjenis kelamin perempuan, 37 $(61,67 \%)$ bekerja sebagai ibu rumah tangga, 23 $(38,33 \%)$ tamat SMA/sederajat, $21(35 \%)$ memiliki anggota keluarga diabetes melitus dan paling besar $(30,76 \%)$ dari ibu kandung dan saudara kandung, 29 $(48,33 \%)$ melakukan aktivitas fisik sedang, dan 55 $(91,67 \%)$ mengkonsumsi makanan/minuman manis dan olahan dari tepung terigu $\geq 3$ kali perminggu. Usia $\geq 45$ tahun 4,97 kali lebih berisiko untuk terkena diabetes melitus tipe 2. Adanya riwayat keluarga diabetes melitus 4 kali lebih berisiko untuk terkena diabetes melitus tipe 2. Semakin ringan aktivitas fisik yang dilakukan maka semakin besar risiko untuk terkena diabetes melitus tipe 2, sedangkan aktivitas fisik sedang justru dapat menurunkan risiko diabetes melitus tipe 2, dan kebiasaan makan yang tidak baik lebih berisiko terkena diabetes melitus tipe 2 .

Adapun saran yang dapat disampaikan oleh peneliti yaitu masyarakat sebelum berusia 45 tahun sebaiknya melakukan cek kesehatan berkala untuk mendeteksi dini faktor risiko diabetes melitus tipe 2 ke pelayanan kesehatan. Puskesmas Talang Bakung sebaiknya melakukan agenda rutin pengecekan kadar gula darah dan melakukan monitoring, meningkatkan upaya promosi kesehatan tentang faktor risiko, tanda dan gejala, komplikasi serta pengendalian diabetes melitus tipe 2, promosi kesehatan tentang pola hidup bersih dan sehat. Fakultas kesehatan masyarakat sebaiknya dapat menambah sumber bacaan atau referensi terkait dengan diabetes melitus tipe 2, dan kepada peneliti selanjutnya agar dapat melakukan penelitian lebih lanjut faktor risiko diabetes melitus tipe 2 yang belum diteliti dalam penelitian ini. Selain itu dapat pula melakukan penelitian dengan desain study yang berbeda dan dapat memperbesar jumlah sampel agar hasil penelitian lebih representatif.

\section{DAFTAR PUSTAKA:}

1. WHO, 2016. Global Report On Diabetes. World Heath Organization.

2. Masriadi. 2016. Epidemiologi Penyakit Tidak Menular. Jakarta: Cv. Trans Info Media.

3. Kemenkes RI. 2016. Ayo cegah diabetes dengan cerdik. [online]. (diupdate 7 April 2016) http://www.depkes.go.id/article/print/1604070000 2/menkes-mari-kita-cegah-diabetes-dengancerdik.html. [diakses 9 September 2017].

4. IDF, 2017. IDF Diabetes Atlas Eighth Edition 2017. International Diabetes Federation.

5. Kemenkes RI, 2007. Riset Kesehatan Dasar (Riskesdas 2007). Badan Penelitian dan Pengembangan Kesehatan Departemen Kesehatan, Republik Indonesia.

6. Kemenkes RI, 2013. Riset Kesehatan Dasar (Riskesdas 2013). Badan Penelitian dan Pengembangan Kesehatan Departemen Kesehatan RI.

7. Kemenkes RI, 2007. Laporan Hasil Riset Kesehatan Dasar (Riskesdas) Provinsi Jambi Tahun 2007. Badan Penelitian dan Pengembangan Kesehatan Departemen Kesehatan RI.

8. Kemenkes RI, 2013. Riset Kesehatan Dasar dalam Angka (Riskesdas 2013) Provisi Jambi. Badan Penelitian dan Pengembangan Kesehatan Departemen Kesehatan Republik Indonesia.

9. Dinkes Kota Jambi, 2017. Laporan 10 Penyakit Terbesar di Kota Jambi. Dinas Kesehatan Kota Jambi.

10. Bustan, N. 2015. Manajemen penyakit tidak menular. Jakarta: Rineka Cipta.

11. Irawan. 2016. Epidemiologi Penyakit tidak Menular. Yogyakarta: Deepublish.

12. Sharma, R., Prajapati. P.K., 2015. Rising risk of type 2 diabetes among inhabitants of Jamnagar, Gujarat: A cross-sectional survey. [Online] 4 Nov.,

36.http://www.ayujournal.org/article.asp?issn=09 748520; year $=2015$; volume $=36 ;$ issue $=1 ;$ spage $=10$ ;epage $=17$; aulast $=$ Sharma [diakses 3 Juni 2018].

13. Ekowati, Rahajeng. 2010. Pengaruh konsumsi kopi terhadap kejadian diabetes melitus tipe 2 . Gizi Indon 2010., 33(2). p. 82-95.

14. Meidikayanti, W \& , Wahyuni, C.U. 2017. Hubungan dukungan keluarga dengan kualitas hidup diabetes melitus tipe 2 di Puskesmas Pademawu. Jurnal Berkala Epidemiologi, 5(2), p. 240-252.

15. Angelina, B. \& Syukrina, N. 2011. Patologi pada Kehamilan. Jakarta: EGC. 
16. Rahmanian, K., Shojaei, M \& Jahromi, A.S. 2013. Relation of type 2 diabetes mellitus with gender, education, and marital status in an Iranian urban population. [Online] 13 Apr., https://www.ncbi.nlm.nih.gov/pmc/articles/PMC4 757057/ [diakses 18 Juli 2018].

17. Silva, E.F.F., Ferreira, C.M.M., \& Pinho, L.D. 2016. Risk factors and complications in type 2 diabetes outpatients. Rev Assoc Med Bras 2017, 63(7), p. 621-627.

18. Prasetyani, D \& Sodikin. 2017. Analisis faktor yang mempengaruhi kejadian diabetes melitus (dm) tipe 2. Jurnal Kesehatan Al Irsyad (JKA), 10(2).

19. Sakurai, M., Nakamura, K., Miura, K., et al. 2013. Family history of diabetes, lifestyle factors, and the 7-year incident risk of type 2 diabetes mellitus in middle-aged Japanese men and women Journal of Diabetes Investigation, 4(3).

20. Kusnadi, G., Murbawani, E.A., \& Fitranti, D.Y. 2017. Faktor risiko diabetes melitus pada petani dan buruh. Journal of Nutrition College, 6(2).

21. Diabetes UK. 2012. Diabetes in the UK: Key Statistics on Diabates.

22. Tentero, I.N., Pangemanan, D.H.C., \& Polii, H. 2016. Hubungan diabetes melitus dengan kualitas tidur. Jurnal $e$ Biomedik (eBm),4(2).

23. Noermalawati, V., \& Wirjatmadi, R.B. 2014. Hubungan ketepatan diet dan kejadian obesitas dengan kadar gula darah puasa pasien diabetes melitus tipe 2 dengan komplikasi. Jurnal Widya Medika Surabaya, 2(2).

24. Nur, Abidah., Fitria, Eka., Zulhaida, Andi., dkk, 2016. Hubungan pola konsumsi dengan diabetes melitus tipe 2 pada pasien rawat jalan di RSUD Dr. Fauziah Bireuen Provinsi Aceh. Media Litbangkes, 26(3), p.145-150.

25. Paramitha, Gumilang Mega. 2014. Hubungan aktivitas fisik dengan kadar gula darah pada pasien diabetes melitus tipe 2 di rumah sakit umum daerah karanganyar. Skripsi sarjana. Fakultas Kedokteran. Universitas Muhammadiyah, Surakarta.

26. Betteng, R., Pangemanan, D. \& Mayulu, N. 2014. Analisis faktor resiko penyebab terjadinya diabetes melitus tipe 2 pada wanita usia produktif di puskesmas wawonasa. Jurnal e-Biomedik (eBM,. 2(2).

27. Iroth, Gratia S.N., Kandau, Grace D., \& Malonda, Nancy S.H. 2015. Hubungan antara umur dan pola makan dengan kejadian diabetes melitus tipe 2 pada pasien rawat jalan di Kelurahan Tenga Kecamatan Tenga. Fakultas Kesehatan Masyarakat.

28. Dolongseda, F.V., Masi, Gresty, N.M., \& Bataha, Yolanda B, 2017. Hubungan pola aktivitas fisik dan pola makan dengan kadar gula darah pada pasien diabetes melitus tipe ii di poli penyakit dalam rumah sakit Pancaran Kasih Gmim Manado. E-journal Keperawatan (e-Kp),5(1).

29. Sami, W., Ansari, t., Butt, N.S., et al. 2017. Effect of diet on type 2 diabetes mellitus: A review. International Journal of Health Sciences, 11(2).

30. Sotir, L.J. 2011. A processed food diet: a major risk factor for type 2 diabetes. Whole Health \& Nutrition [Online] (diaupdate 2015), http://www.wholehealthandnutrition.com/article.p hp?article=29 [diakses 4 Juni 2018]. 